\title{
Diversity, distribution and status of bats on the Andaman and Nicobar Islands, India
}

\author{
Bandana Aul, P.J.J. Bates, D.L. Harrison and G. Marimuthu
}

\begin{abstract}
Information on the bat fauna of the Andaman and Nicobar Islands was limited previously to the results of sporadic surveys, with no specific focus on the habitats or distribution of the species. We carried out the first extensive survey of the Andaman and Nicobar Islands during 2003-2006, covering 40 islands. Our objective was to map the bat species, their habitats and distribution. This resulted in identification of 25 bat species representing 13 genera, location of $>300$ roosts and validation of previously recorded species. Notable findings included the rediscovery of the endemic Nicobar flying fox Pteropus faunulus after a century and its extinction from the type locality on Car Nicobar Island, the sighting of an albino Hipposideros diadema nicobarensis from Katchal Island, and the first records of Rhinolophus yunanensis, Murina cyclotis and Hipposideros larvatus from the Andaman Islands, and Taphozous melanopogon, Murina cyclotis, Pipistrellus spp., Myotis horsfieldii dryas and Cynopterus brachyotis from the Nicobar Islands. Threats to the bat fauna appear to be primarily roost disturbance and hunting for sport. Anthropogenic pressure on species of Pteropus is high as hunting occurs throughout the year. Secondary sources and our field observations confirmed the decline of Pteropus in several islands as a result of hunting and alteration to habitats. We introduced a community initiative to monitor and protect roosts and foraging sites close to settlements in the Nicobar Islands. Priorities identified for conservation of the bat fauna of the archipelagos are mitigation of threats to flying foxes and cave dwelling bats, initiation of research on endemic bat species such as $P$. faunulus, and a voluntary ban by local communities on hunting in specific areas and seasons.
\end{abstract}

Keywords Andaman and Nicobar Islands, bats, community initiative, local extinction, new records, Pteropus faunulus

This paper contains supplementary material that can be found online at http://journals.cambridge.org

BANDANA Aul (Corresponding author) Department of Animal Behaviour \& Physiology, Madurai Kamraj University, Madurai 6250421, India. E-mail bandana_aul@rediffmail.com

P.J.J. BATES and D.L. HARRISON Harrison Zoological Museum, Centre of Systematics and Biodiversity Research, Sevenoaks, Kent, UK

G. Marimuthu Department of Animal Behaviour \& Physiology, School of Biological Sciences, Madurai Kamaraj University, Madurai, Tamil Nadu, India

Received 26 December 2011. Revision requested 27 February 2012.

Accepted 8 May 2012. First published online 21 February 2014.

\section{Introduction}

lthough the Andaman and Nicobar Islands are A politically a part of the Indian subcontinent, they have biogeographical affinities with Sumatra and the Lesser Sundas (Rodgers \& Panwar, 1988; Das, 1999). The mammalian fauna of these islands comprises a rich assemblage of rodents and bats (Miller, 1902; Hill, 1967; Nath \& Chatervedi, 1975; Saha, 1980; Das, 1990; Pande et al., 1991); 13\% of the 5,357 recorded animal species are endemic (Rao, 1984). This excludes the marine mammals, none of which are endemic. Endemism is pronounced in $39 \%$ of the 270 species and subspecies of birds (Das, 1971; Abdulali, 1974), $55 \%$ of the 58 mammal species, $32 \%$ of the 83 reptile species and $20 \%$ of the 10 amphibian species (Rao \& DevRoy, 1985; Andrews \& Sankaran, 2002). Common terrestrial mammals include the Andaman wild pig Sus scrofa andamanensis, crab eating macaque Macaca fascicularis umbrosa, Andaman masked palm civet Paguma larvata tytlerii, Andaman spiny shrew Crocidura andamanensis, Nicobar tree shrew Tupaia nicobarica nicobarica, Andaman horse-shoe bat Rhinolophus cognatus and lesser short-nosed bat Cynopterus brachyotis. Introduced mammals include the spotted deer Axis axis (now occurring throughout South, Middle and North Andaman Islands), goats Capra sp. (on Barren and Narcondum Islands) and elephant Elephas maximus (on Interview Island).

Bats are sensitive to habitat disturbance and landscape changes from anthropogenic activities (Zubaid, 1993; Struebig et al., 2008) and could be used as indicator species. Previous records (Supplementary Table S1) of bat species in the Andaman and Nicobar Islands are the result of faunal exploration and collection of species (Hill, 1967, 1971; Abdulali, 1976a,b; Rao et al., 1994; Das, 1998, 1999; Deb, 1998). Miller (1902) listed 12 bat species and other small mammals, and provided the first description of the endemic fruit bat Pteropus faunulus, from Car Nicobar Island. Bates \& Harrison (1997) compiled a list of 23 species from museum specimens and records (e.g. Miller, 1902; Hill, 1967).

Here we report the first extensive survey of the bats of the Andaman and Nicobar Islands and the threats to these species from hunting and disturbance in their day roosts. We focused on identifying the distribution of species across the islands, validating past records and mapping roosts. We also attempted to initiate community participation in conservation of bats by proposing a voluntary hunting ban and adoption of roosts close to settlements 
on inhabited islands. This is especially applicable in the Nicobar Islands where the wildlife laws favour the indigenous communities, who have been granted special hunting rights under Section 56 of the Indian Wildlife (Protection) Act, 1972 (Anon, 1994). In a pilot radio-tracking study we successfully tracked $11 P$. faunulus, locating a day roost and the foraging range.

\section{Study area}

The Andaman and Nicobar Islands (Figs 1 \& 2) lie in the Bay of Bengal between India and Myanmar, parallel to the coast of Myanmar. The Andaman Islands are separated from the Nicobar Islands by the Ten Degree Channel. Both the island groups have a tropical climate throughout the year, with temperatures of $18-34^{\circ} \mathrm{C}$, a mean annual rainfall of $3,000-3,500 \mathrm{~mm}$, and relative humidity of $75-95 \%$. The forest can be broadly classified as tropical evergreen. Grasslands are unique to the Central Nicobar Group (Pande et al., 1991). The topography of the islands is hilly and undulating; maximum altitudes are $732 \mathrm{~m}$ at Saddle Peak on North Andaman Island and $568 \mathrm{~m}$ at Mt Thullier on Great Nicobar Island (Southern Nicobar Group; Oldham, 1885). Among the total of 306 islands in the archipelagos 33 are inhabited and 94 are designated as Sanctuaries, including two islands in the Andaman Islands that are tribal reserves. The entire Nicobar Islands are under the provisions of the Andaman and Nicobar Protection of Aboriginal Tribes Regulation of 1956 and entry to them is restricted to Indian nationals.

\section{Methods}

Surveys of the large islands and representative samples of small islands were carried out on 26 islands (39 sites) in the Andaman Islands and 14 islands (20 sites) in the Nicobar Islands (Figs 1 \& 2) during 2003-2006. We made an additional survey after the occurrence of the tsunami that resulted from the Sumatra-Andaman earthquake of 26 December 2004, to record any damage to cave roosts and roosts of Pteropus melanotus, particularly in the mangrove forest belts. Secondary data on hunting, and locations and shift of roosts were regularly obtained from locally trained individuals during 2008-2011.

Standard ground-level mist nets were deployed between 17.00 and 02.00 , monitored every 30 minutes, for 121 and 160 nights in the Andaman and Nicobar Islands, respectively. Four nets were deployed at a distance of $500 \mathrm{~m}$ from each other at each site, resulting in a total of 1,124 sample nights. Sub-canopy and canopy nets were used for species flying above the lower strata. Nets were deployed in plantations with and without water bodies. The plantations, planted mainly by the horticulture departments of the Andaman and Nicobar Islands, were mostly of banana, mango and guava. These plantations are not for commercial purposes and are mostly to supplement the diet of people in the settlements. Nets were also deployed in primary forests and secondary forest with and without streams. Unique habitats such as freshwater swamps and fringing forest habitats with grasslands, mangroves and littoral forests were also sampled. These unique habitats are restricted in extent. For example, Little Andaman Island is the only island with freshwater swamps, and grasslands are restricted to the Central Nicobar Group. All bats captured were kept in cloth bags and released at point of capture after data collection. Data collected included length of fore arm, sex, weight and pelage colour. In accordance with internationally accepted procedures (Kunz, 2009), nets over streams were set at a height to ensure the last shelf was well above the water, to avoid drowning of captured individuals.

Net nights were calculated by multiplying the number of nets deployed by the number of nights of sampling at each site. Capture success for each species, by island, was calculated as the total number of individuals of a species captured on an island divided by the total number of individuals of all species combined captured on the island, multiplied by 100. Species richness of a site is the total number of bat species recorded.

Day roosts were identified from earlier records (Sankaran, 1998) through informal discussions with inhabitants, and searches of potential sites. At each roost the species present and the roost type were recorded. Population sizes were estimated by counting the individuals of each species.

Caves surveyed were within the forest and at the seashore. Caves within forest were cracks in the rocks, in undulating terrain, below the ground and on inland hills, where they occurred as clefts or cracks under a rocky hill, forming large cave complexes. There are such complexes at Cliff Bay Sanctuary (41 caves) in the North Andaman Group, and Interview Island (34 caves) and Baratang Island (190 inland forest caves, including some small caves) in the Middle Andaman Group. We did not locate any cave complexes in the Nicobar Islands. Where entry by adults to caves was not possible mist nets on entrances were used to ascertain the presence or absence of bats. Upon identification of roosts we attempted to explore all accessible areas, record the species present in each cave and count the approximate numbers in each roost.

Two hundred and seventy interviews were conducted in 150 villages across the islands, during which we collected data on hunting prevalence and intensity and on any preferences for bat meat in the diet. We interviewed both settlers (people not originally from the archipelagos: Tamil, Telugu, Bengali and Karen) and tribal communities (Great Andamanese, Onge and Nicobarese). We did not survey in the tribal areas inhabited by the Jarawa and 


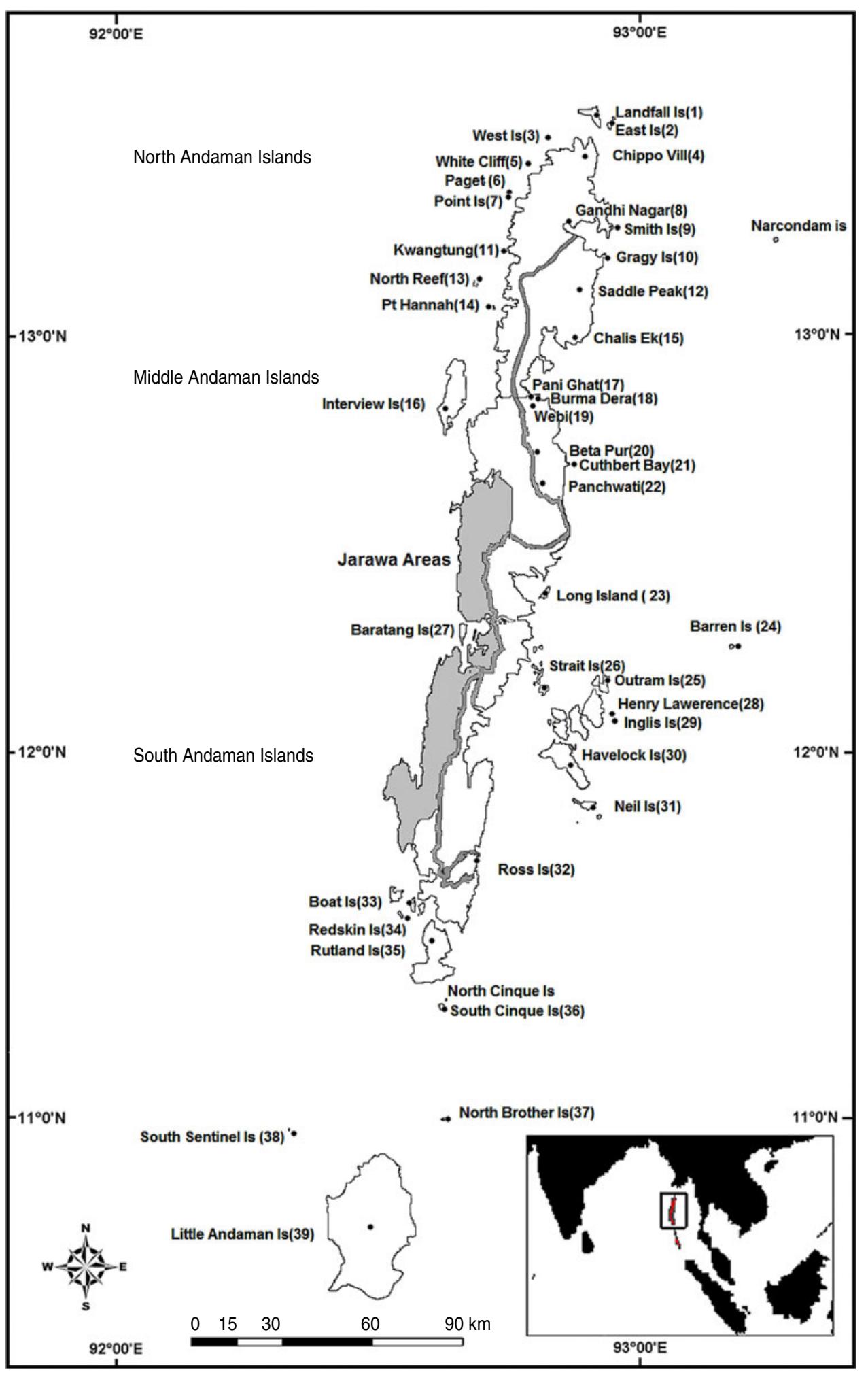

FIG. 1 The Andaman Islands, showing the locations of the survey sites (numbered, for names see Supplementary Table S2). The rectangle on the inset indicates the location of the islands in the Indian Ocean.
Sentanalese, in the Andaman Islands, and by the Shompen, on Great Nicobar Island, as entry to these areas is prohibited. In the Nicobar Islands the Nicobarese were interviewed, to gather additional information on any hunting preference for the two sympatric flying fox species, P. melanotus and P. faunulus, and on the presence of $P$. faunulus in the Central Nicobar Group. We captured these two Pteropus species in plantations close to settlements in the Nicobar Islands but these catches were not included in the mist net captures as they were a deliberate attempt to capture these species and would have biased the reporting of overall percentage capture success. 


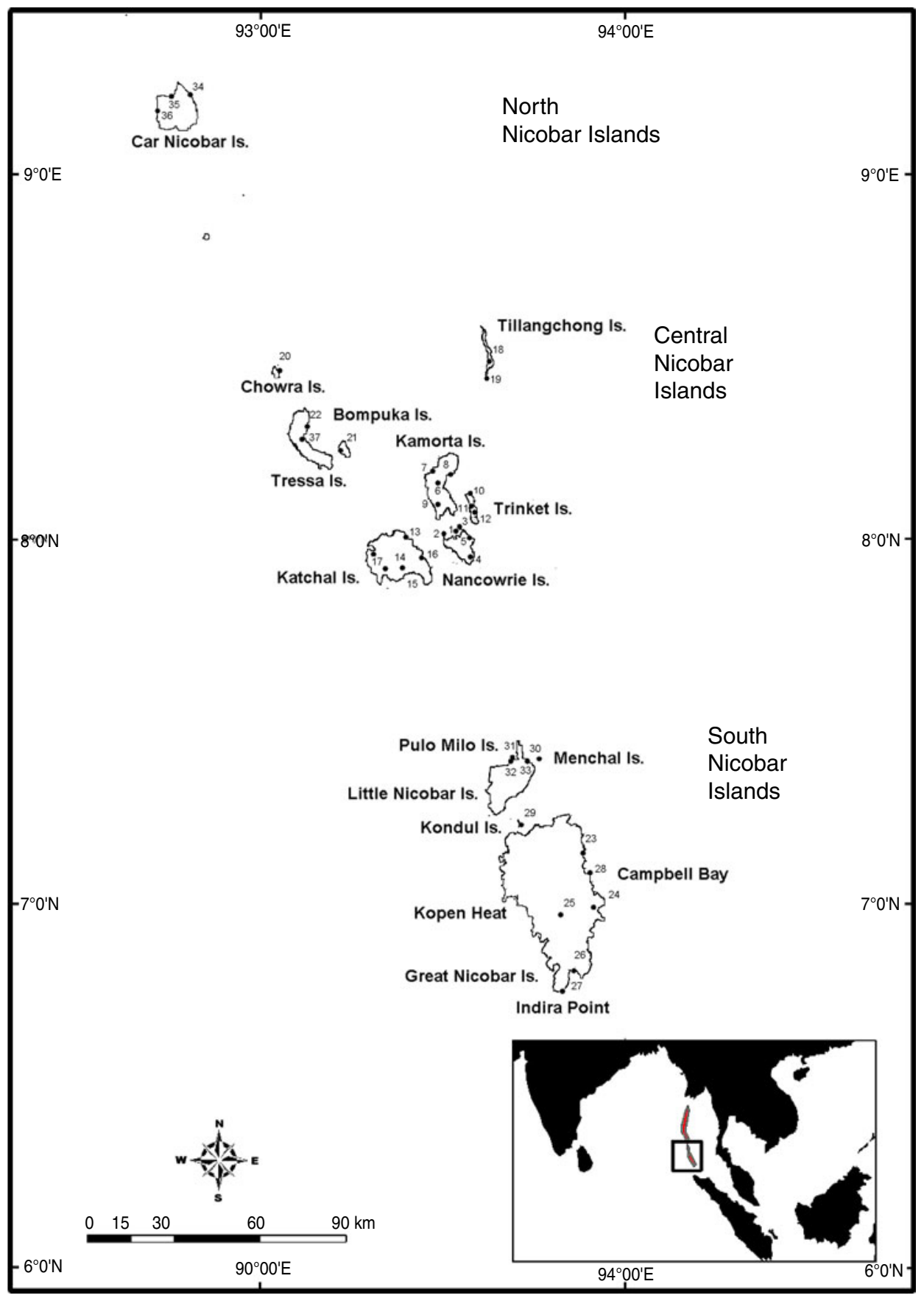

FIG. 2 The Nicobar Islands, showing the locations of the survey sites (numbered, for names see Supplementary Table S2). The rectangle on the inset indicates the location of the islands in the Indian Ocean.

We conducted pilot radio-tracking during JanuaryMarch 2006 to locate the day roosts of $P$. faunulus. Eleven individuals (nine males and two females) were tracked from 18.00 to 03.00 , for 45 days, to estimate their foraging range. The roosts of the tagged individuals were identified by triangulation (Kunz, 2009). Type PD-2C collars (Holohil Systems Ltd, Ontario, Canada), weighing $3.25 \mathrm{~g}$ and with a battery life of 12 weeks, were used. A TRX $2000 S$ receiver (Wildlife Materials Ltd, Carbondale, USA) with a 3-element Yagi antenna (Wildlife Materials, Carbondale, USA) was used for tracking.
The status of each species recorded was determined using the survey data and their IUCN Red List status (Leary et al., 2008; Supplementary Table S1). A total of 52 voucher specimens were retained from the surveys (two females and two males of each species) and were deposited in the Zoological Survey of India, Kolkata.

\section{Results}

We identified a total of 25 species of bats, representing 13 genera. In the Nicobar Archipelago we captured bats of 
eight genera and in the Andaman Archipelago we captured bats of 12 genera (including the eight genera captured in the Nicobar Archipelago; Supplementary Table S1). A list of the species recorded on each island is provided in Supplementary Table S2. Various notes describing the species recorded, including measurements and pelage colour, are provided in Supplementary Material 1.

\section{Mist netting}

We captured a total of 612 individuals of 17 species in the Andaman Islands and 772 individuals of 14 species in the Nicobar Islands, in a total of 1,124 net-nights. Insectivorous and frugivorous species comprised 70.8 and $29.2 \%$ of the catches, respectively. Of the various habitats sampled the percentage capture success was highest in gallery forest, followed by secondary forest in which there were freshwater streams.

Species richness was low in habitats such as plantations/ monocultures, mangroves and forest fringes in the Andaman Islands and in forest grassland fringes in the Nicobar Islands. Species captured in these habitats were Cynopterus sp., Cynopterus sphinx, Cynopterus brachyotis and Eonycteris spelaea in the Andaman Islands, and C. sphinx and C. brachyotis in the Nicobar Islands. Habitats such as freshwater swamps are restricted to Little Andaman Island. In these habitats the total number of individuals captured in mist nets was low but, compared to other habitats, the number of species was high. In the Andaman Islands species capture success was higher in the North Andaman Group (41.6\%, 13 species) and Little Andaman (24.7\%, 7 species) followed by the South (18.7\%, 8 species) and Middle Andaman Group (14.9\%, 9 species). In the Nicobar Islands species capture success was higher in the Central and Northern Nicobar Groups (83.9\%, 9 species) than in the Southern Nicobar Group (16.4\%, 8 species). However, species richness in the North Nicobar Group was lower, with only five species, than the Central and South Nicobar Group, where we recorded 12 and eight species, respectively. Among the pteropodids the greatest capture success was of Cynopterus spp., in both the Archipelagos. The distribution of Cynopterus sp. and Eonycteris spelaea is restricted to the Andaman Islands. E. spelaea was captured only in plantations, gallery forest and over freshwater streams, whereas Cynopterus sp. was recorded from gallery forests, plantations and over freshwater streams. $P$. melanotus was identified in day roosts and from specimens hunted in village settlements on both the Andaman and Nicobar Islands. P. faunulus was restricted to the Central Nicobar Group.

Species captured occasionally in nets were Tylonycteris pachypus at Webi (Middle Andaman Island), Hesperotenus tickelii (Webi and Interview Island; Middle Andaman Group), Hipposideros pomona in Menchal Island (South
Nicobar Group) and H. tickelii in the Andaman Islands. These species were captured in gallery forest in nets set over freshwater streams. Murina cyclotis was captured on four occasions over freshwater streams and in gallery forests in Interview Island and at Chippo Village in the North Andaman Group, and in the Nicobar Islands it was captured in similar habitats on 11 of the 14 islands surveyed. Details of the capture success of each species in the various habitats are given in Supplementary Table $S_{3}$.

\section{Roosts}

The survey of roosts included caves, bridges, crevices, road culverts, abandoned buildings, foliage and tree hollows (Supplementary Table $S_{4}$ ). We surveyed a total of 116 and 54 caves in the Andaman and Nicobar Islands, respectively (Supplementary Table S5), including caves newly discovered by us (two on Point Island in the North Andaman Group, four on Little Andaman Island and six on Tressa Island in the Central Nicobar Group; Aul, 2003, $2006,2007)$. We found only one species in 87 caves, $2-3$ species in 28 caves and in 55 caves we found no bats. In the Andaman Islands bats that occupied caves were C. brachyotis, E. spelaea, Taphozous melanopogon, Megaderma spasma, Rhinolophus yunanensis, R. cognatus, Rhinolophus famulus. Hipposideros fulvus, Hipposideros larvatus, Myotis horsfieldii dryas and Pipistrellus javanicus. In the Nicobar Group the species were T. melanopogon, Hipposideros nicobarulae, H. pomona, Hipposideros diadema nicobarensis, Miniopterus pusillus, Pipistrellus javanicus and Pipistrellus coromandra camortae. We sighted an albino $H$. diadema nicobarensis in the cave on Katchal Island in February 2005 (Aul \& Marimuthu, 2006). Pit vipers Trimeresures spp. and a monitor lizard Varanus salvator were recorded feeding on swiftlets and bats in one cave on Cliff Bay and three on Interview Island (North Andaman Group) and two seashore caves on Little Nicobar Island (South Nicobar Group) and two on Katchal Island (Central Nicobar Group; Aul \& Vijayakumar, 2003; Aul, 2007).

Pteropus spp. and Cynopterus spp. were found roosting in trees. P. melanotus, in colonies of 200 to $>1,500$ individuals were found on Interview, North Reef, Point, Paget and the Landfall Islands of the North Andaman Group, Havelock and Outram Islands in the South Andaman Group and in Dugong creek on Little Andaman Island. These roosts were located in mangrove and inland forest canopy trees. Pteropus hypomelanus was recorded only from Barren Island, in the Middle Andaman Group, roosting in trees $<_{4} \mathrm{~m}$ in height on slopes. In the Nicobar Islands we recorded two colonies of $P$. melanotus, one with 50 to $<600$ individuals on Tillangchong Island and one with 50 to $<200$ individuals in a mangrove forest on Great Nicobar Island. 
P. faunulus is endemic to the Central Nicobar Group and was rediscovered, after 100 years, during the present survey (Aul, 2006). It was not recorded from its type locality (Car Nicobar Island; Miller, 1902) and is probably locally extinct from this island. Nine males and two females of $P$. faunulus were tracked to locate their day roosts on Kamorta Island. Roost sites were distinct from foraging areas, with the males appearing to roost closer to foraging areas $(2.11-12.35 \mathrm{~km})$ than females $(7.49-10.82 \mathrm{~km})$. One radio-collared individual was tracked to a hunter's home, from whom the tag was recovered.

C. brachyotis was found in groups of $<5$ individuals, occupying the fronds of Cocos nucifera. We observed single individuals of $C$. brachyotis in trees close to the entrance of the caves on Interview Island in the North Andaman Group. Megaderma spasma and $R$. cognatus used tree hollows as roosts on the Andaman Islands. Such roosts were not abundant on the Nicobar Islands and were recorded only on Tillangchong and Tressa Islands in the Central Nicobar Group, and were utilized by P. coromandra and H. fulvus (Supplementary Table S4).

\section{Threats}

In 270 interviews, discussions and observations we noted that hunting for sport was the prime threat to flying foxes, followed by habitat clearance for settlements. It was apparent that there is no dependence on bat meat as a protein supplement. Hunting is restricted to foraging bats and to roosts close to human settlements (of settlers in the Andaman Islands and of the Nicobarese in the Nicobar Islands). The size of colonies roosting away from settlements (e.g. Middle and Little Andaman Islands and Central Nicobar Group) was usually larger (100 to $>2,000$ individuals) than that of colonies roosting closer to settlements $(<200$ individuals). At Dugong creek the Onge people live in the vicinity of one of the largest $P$. melanotus roosts but no hunting of bats was recorded at this site.

Our further observations confirmed the prevalence of hunting in villages where settlers reside in the Andaman Islands. Some communities, particularly of the Karen from the North Andaman Group, travel as far as Barren Island to hunt bats and feral goats. The Nicobarese, excluding the Shompen tribes, mostly hunt flying foxes whilst the bats are foraging (18.00-20.00) during the flowering of Ceiba sp. during January-March. Although air guns are commonly used, catapults are occasionally used in the Nicobar Islands.

Secondary sources confirmed the decline of populations of Pteropus spp.. It appears there is no preference for hunting particular Pteropus species. There is a prevalent belief in the medicinal properties of bat meat but no confirmation of its healing properties was validated by people who had consumed bat meat. Reports in 2010 indicated that hunting during the flowering period of Ceiba sp. had been voluntarily banned in the settlements on Kamorta and Trinket Islands, where hunting was formerly common.

Indirect threats are primarily to the cave dwelling species, resulting from disturbance during collection of nests of the edible nest swiftlet Collicalia fuciphaga, mainly in the Andaman Islands. Baratang Island is an important site as it has nine species of bats and one of the largest cave complexes (with 190 caves) in the Andaman Islands. Excessive cave tourism on Baratang Island (Middle Andaman Group), particularly during October-March, caused bats to abandon their roosts. We cannot ascertain the time of abandonment but during the previous survey, in 2003, these caves contained bats; in 2006 they were vacant. Bright lighting and the influx of tourists might have driven the bats away from some of these caves. Disturbance in caves is minimal in the Nicobar Islands and is restricted to poachers from Myanmar and Thailand during May-June.

\section{Impact of the 2004 tsunami}

The 2004 Indian Ocean tsunami partially affected the mangroves of the Andaman Islands and completely destroyed the mangroves of the Nicobar Islands. In the Andaman Islands no shifting of roosts of $P$. melanotus were recorded whereas in the Nicobar Islands the colonies of P. melanotus in Great Nicobar and Tillangchong Islands moved to inland forest areas. During a resurvey in 2006 in Tillangchong Island we confirmed that recovery of $\mathrm{Nypa}$ fruticans had facilitated the return of the colonies of P. melanotus.

According to Manchi \& Sankaran (2009) caves were minimally affected and a limited number of larger caves had observable damage at Challis Ek (North Andaman Group). During our resurvey in 2007 we found that the roosts in these caves had not been abandoned. However, coastal caves in the Nicobar Islands were affected, with bats vacating caves whose entrances were partially or completely submerged.

\section{Discussion}

Species inventories are important for identification of priority areas for conservation but the efficacy of such inventories is dependent on the quality of inventory data available (Struebig et al., 2010). Although bats comprise $20 \%$ of all mammalian species the understanding of factors influencing their community structure in fragmented habitats is limited (Racey \& Entwistle, 2003; Frick et al., 2008). Lack of adequate information about bat diversity and distribution hamper effective conservation (Costa et al., 2005; Palmeirim et al., 2007). Earlier reports on the bat fauna of the Andaman and Nicobar Islands 
(Miller, 1902; Bates \& Harrison, 1997) included Taphozous saccolaimus and Scotophilus kuhlii $($ Hill, 1967) but these two species were not found during our survey. Das (1998) reported the presence of Hipposideros cineraceus on $\mathrm{Mt}$ Harriet but visual identification of the image in the article suggests it is $M$. cyclotis. As we did not record them, $T$. saccolaimus, S. kuhlii and H. cineraceus are excluded in our list of species for the islands.

We identified a total of 25 bat species, including two new records and two new subspecies (Hipposideros ater nicobarulae has renamed H. nicobarulae; Bounsavane et al., 2011; Murina cyclotis has been reassessed as a new sub species in the Nicobar Islands; Soisook et al., 2013). Mist netting in a range of habitats provided preliminary information on bat assemblages across the islands and their various habitats. Information on Pteropus spp. in the archipelagos is sporadic, with no mention of roosts or diet, and thus their role as pollinators can only be presumed from studies on other islands, where Pteropus spp. are important pollinators and seed dispersers. Pteropus vampyrus has been recorded as a seasonal migrant to the Nicobar Islands (Rao et al., 1994) but was not recorded during our survey and was not included in our final list of species for the islands. The rediscovery of $P$. faunulus and its apparent extinction from its type locality emphasizes the importance of having baseline information that includes habitat requirements, diet and threats. Such information will be critical for developing management and developmental plans for the islands. P. hypomenalus has been reported from Narcondum and Barren Islands and although we recorded it from Barren Island it seems morphometrically similar to P. melanotus.

Biodiversity loss on islands is a result of deforestation and anthropogenic activities (Fritts \& Roda, 1998; Cincotta et al., 2000; Myers et al., 2000) that simultaneously modify the composition or structure of the landscape and vegetation (Coreau \& Martin, 2007). Threats to the bat fauna of the Andaman and Nicobar Islands are mainly from hunting and habitat modification (Deb, 1998), the latter principally from the loss of potential roost sites. Wild animals, particularly pteropodids, are part of the diet of local human communities (García \& Goodman, 2003; Golden, 2009) and are threatened throughout their geographical range (Cheke \& Dhal, 1981; Wiles, 1987; Rainey, 1990; Craig et al., 1994; Wiles et al., 1997; Brooke \& Tschapka, 2001; Mohd-Azlan et al., 2001; Mickleburgh et al., 2009). Although hunting of insectivorous bats has been observed in Madagascar (Goodman, 2006; Cardiff et al., 2009) there are no such reports from the Andaman and Nicobar Islands. In the Andaman and Nicobar Islands insectivorous bats are being disturbed by collection of nests of the edible nest swiftlet, and by cave tourism on Baratang Island. Hunting is prevalent on the islands despite inclusion of some of the hunted species in the protected list of the Indian Wildlife
(Protection) Act, 1972, and the Amended Acts, 2002. In addition to the hunting of bats we witnessed the hunting of a crocodile Crocodylus sp., the green turtle Chelonia mydas and pigeons Ducula spp. in the Central and Southern Nicobar Groups.

Section 56 of the Indian Wildlife (Protection) Act, 1972 provides special hunting rights for the indigenous communities of the Nicobar Islands. Such rights need to be reassessed, however, and hunting for subsistence or protein supplement should be clearly defined following an identification of the needs of the local communities. Pteropus species are the largest native mammals on the archipelagos and could be critical in the dispersal and pollination of some key plant species. Protection of their foraging sites in and around settlements is therefore required.

Fruit bat roosts are larger when they are further from human settlements (Krueger \& O’Daniel, 1999). We observed $>2,000$ Pteropus in roosts situated away from settlements but $<500$ in roosts closer to settlements. Our observation of the destruction of major Pteropus roosts in mangroves by the 2004 tsunami indicates that natural calamities can also have serious effects on bat populations.

Establishment of protected areas may be particularly effective for the conservation of species with wide geographical distributions on larger land masses (Rodrigues et al., 2004) but scattered protected areas, even in smaller regions, may not include all the species that require conservation. In the Nicobar Archipelago only four islands (Battimalv, Tillangchong, Megapode and Great Nicobar) are protected. Little Nicobar and Bompuka, which have many endemic plant and animal species, are not included in the protected area network (Abdulali, 1976a,b; Sankaran, 1997, 2001). Any protected area in the Nicobar Group would need to be established with the support of the tribal communities, to ensure effectiveness. It would also be of value to establish a flagship bat species (e.g. P. faunulus) that could reinforce an inherent cultural association or belief and illustrate the economic and ecological values of conservation (Mickleburgh et al., 1992; Bowen-Jones \& Entwistle, 2002).

We recommend the establishment of a conservation programme involving local stakeholders, and identification of a flagship species (Aul, 2006). The need to conserve endemic species such as P. faunulus arises from the fact that an extremely narrow geographical range increases the likelihood of extinction (Brooks et al., 2002). Our research on the endemic bats of the Andaman and Nicobar Islands has resulted in the formation of a team of trained local people and a voluntary ban on hunting of bats near settlements on Kamorta Island. Roosts closer to settlements are being monitored and protected from land clearance, and information is regularly collected by the local team on any change in bat populations across the islands. 


\section{Acknowledgements}

We thank the Conservation Leadership Programme, Lubee Bat Conservancy, Rufford Foundation and the Andaman and Nicobar Environmental Team for project logistics and support to BA, the Andaman and Nicobar Administration, Chief Wildlife Warden (Andaman and Nicobar) for providing the necessary permit, and Professor Paul Racey and Dr John Raisweiler IV for their guidance and advice. Additional support was provided by the UGC (SAP)-CAS Programme.

\section{References}

Abdulali, H. (1976a) The birds of Great and Car Nicobar with some notes on wildlife conservation in the islands. Journal of the Bombay Natural History Society, 75, 74-77.

A вdulali, H. (1976b) Wildlife in the Bay Islands. Yojana, 20, 72-73. Anderson, K. (1912) Catalogue of the Chiroptera in the collection of the British Museum. I. Megachiroptera. British Museum (Natural History), London, UK.

Andrews, H.V. \& Sankaran, V. (eds) (2002) Sustainable Management of Protected Areas in the Andaman and Nicobar Islands. Andaman and Nicobar Islands Environmental Team, Indian Institute of Public Administration, and Fauna \& Flora International, New Delhi, India.

Anon. (1994) The Wildlife (Protection) Act, 1972 (amended up to 1991). Natraj Publishers, Dehradoon, India.

Aul, B. (2003) The Status and Distribution of Bats in Andaman and Little Andaman Islands. Andaman and Nicobar Islands Environmental Team Technical Report. Madras Crocodile Bank Trust, Mamallapuram, India.

AUL, B. (2006) Status, distribution and ecological studies of the bats in the Andaman and Nicobar Islands with special reference to the Nicobar flying fox (Pteropus faunulus). PhD thesis. Madurai Kamaraj University, Madurai, India.

AuL, B. (2007) Ecology and conservation of the endemic Nicobar Flying Fox (Pteropus faunulus) in the Nicobar group of Islands, India. Final Report submitted to the Conservation Leadership Programme, Cambridge, UK.

Aul, B. \& Marimuthu, G. (2006). Sighting of an albino bat in a colony of cave dwelling microhiropteran, Hipposideros diadema nicobarensis at the Nicobar Islands. Current Science, 90, 912-914.

Aul, B. \& Vijayakumar, S.P. (2003) Bats of Nicobar-Distribution and Conservation Status. Final Technical Report submitted to the BP Conservation Programme, Cambridge, UK.

B A tes, P.J.J. \& HARRISON, D.L. (1997) Bats of the Indian Subcontinent. Harrison Zoological Museum, Sevenoaks, UK.

Bhatacharrya, T. P. (1975) Occurrence of Dobson's long tongued fruit bat, Eonycteris spelaea (Dobson) (Mammalia: Chiroptera: Pteropodidae) in the Andaman Islands, India. Science Culture, $41,317-318$.

Bounsavane, D., Bumrungsri, S., Satasook, C., Soisook, P., Hla Bu, S.S., Aul, B. et al. (2011) A new species of small Hipposideros (Chiroptera: Hipposideridae) from Myanmar and a revaluation of the taxon $H$. nicobarulae Miller, 1902 from the Nicobar Islands. Acta Chiropterologica, 13, 61-78.

Bowen-Jones, E. \& Entwistle, A. (2002) Identifying appropriate flagship species: the importance of culture and local contexts. Oryx, 32, 189-195.
Brooke, A.P. \& Tschapka, M. (2001) Threats from overhunting to the flying fox, Pteropus tonganus, (Chiroptera: Pteropodidae) on Niue Island, South Pacific ocean. Biological Conservation, 7, 1257-1262.

Brooks, T.M., Mittermeier, R.A., Mittermeier, C.G., Da Fonseca, G.A.B., Rylands, A.B., Konstant, W.R. et al. (2002) Habitat loss and extinction in the hotspots of biodiversity. Conservation Biology, 16, 909-923.

Cardiff, S.G., Ratrimomanarivo, F.H., Rembert, G. \& Goodman, S.M. (2009) Hunting, disturbance and roost persistence of bats in caves at Ankarana, northern Madagascar. African Journal of Ecology, 47, 640-649.

Cheke, A.S. \& Dhal, J.F. (1981) The status of bats on the western Indian Ocean islands, with special reference to Pteropus. Mammalia, 45, 205-238.

Cincotta, R.P., Winsnewski, J. \& Engleman, R. (2000) Human population in the biodiversity hotspots. Nature, 404, 990-997.

Coreau, A. \& Martin, J.L. (2007) Multi-scale study of bird species distribution and of their response to vegetation change: a Mediterranean example. Landscape Ecology, 22, 747-764.

Costa, L.P., Leite, Y.L.R., Mendes, S.L. \& Ditchfield, A.D. (2005) Mammal conservation in Brazil. Conservation Biology, $19,672-679$.

Craig, P., Trail, P. \& Morrell, T.E. (1994) The decline of fruit bats in American Samoa due to hurricanes and overhunting. Biological Conservation, 69, 261-266.

DAs, I. (1998) An Ecological Reconnaissance of Rani Jhansi Marine National Park, Andaman Islands, India. Report-Andaman and Nicobar Islands Environmental Team, Port Blair, India.

DAs, I. (1999) A noteworthy collection of mammals from Mt Harriet, Andaman Islands, India. Journal of South Asian Natural History, 4, 181-185.

D As, P. K. (1971) New records of birds from Andaman and Nicobar Islands. Journal of the Bombay Natural History Society. 68, 459-461.

D As, P.K. (1990) Occurrence of Pipistrellus camortae Miller, 1902 (Chiroptera: Vespertilionidae) in the Andaman Islands, with comments on its taxonomic status. Journal of the Bombay Natural History Society, 87, 135-137.

Deв, D. (1998) The Human Ecology of Ritchie's Archipelago: The Anthropogenic Impacts on the Rani Jhansi Marine National Park. Report-Andaman and Nicobar Environmental Team, Port Blair, India.

Frick, W.F., Hayes, J.P. \& Heady, P.A. III (2008) Patterns of island occupancy in bats: influences of area and isolation on insular incidence of volant mammals. Global Ecology and Biogeography, $17,622-632$.

Fritts, P.H. \& Roda, G.H. (1998) The role of introduced species in the degradation of Island ecosystems: a case history of Guam. Annual Review of Ecology and Systematics, 29, 113-140.

García, G. \& Goodman, S.M. (2003) Hunting of protected animals in the Parc National d'Ankarafantsika, north-western Madagascar. Oryx, 37, 115-118.

Golden, C.D. (2009) Bushmeat hunting and use in the Makira Forest, north-eastern Madagascar: a conservation and livelihoods issue. Oryx, 43, 386-392.

Goodman, S.M. (2006) Hunting of Microchiroptera in south-western Madagascar. Oryx, 40, 225-228.

Hill, J.E. (1967) The bats of the Andaman and Nicobar Islands. Journal of the Bombay Natural History Society, 64, 1-9.

Hill, J.E. (1971) A note on Pteropus (Chiroptera: Pteropodidae) from the Andaman Islands. Journal of the Bombay Natural History Society, 64, 1-9.

Krueger, S. \& O’Daniel, D. (1999) Observations of mariana fruit bats on Tinian. Micronesica, 31, 367-371. 
KunZ, T.H. (2009) Ecological and Behavioral Methods for the Study of Bats. 2nd edition. Smithsonian Institution Press, Washington, DC, USA.

Leary, T., Seri, L., Flannery, T., Wright, D., Hamilton, S., Helgen, K. et al. (2008) Zaglossus bruijnii. In IUCN Red List of Threatened Species v. 2013.1. Http://www.iucnredlist.org [accessed 26 September 2013].

MANCHI, S. \& SANKARAN, R. (2009) Impact of the great earthquake of 2004 on limestone caves in North and Middle Andaman Islands, India. Current Science, 97, 1230-1234.

Mickleburgh, S.P., Hutson, A.M. \& Racey, P.A. (1992) Old World Fruit Bats: An Action Plan for their Conservation. IUCN, Gland, Switzerland.

Mickleburgh, S.P., Waylen, K. \& Racey, P.A. (2009) Bats as bushmeat: a global review. Oryx, 43, 217-234.

Miller, G.S. (1902) Mammals of the Andaman and Nicobar Islands. Proceedings of the United States National Museum, 24, 751-795.

Mohd-Azlan, J., Zubaid, A. \& KunZ, T.H. (2001) Distribution, relative abundance and conservation status of the large flying fox, Pteropus vampyrus, in peninsular Malaysia: a preliminary assessment. Acta Chiropterologica, 3, 149-162.

Myers, N., Mittermeier, R.A., Mittermeier, C.G., Da Fonseca, G.A.B. \& Kent, J. (2000) Biodiversity hotspots for conservation priorities. Nature, 403, 853-858.

Nath, B. \& Chatervedi, Y. (1975) On a collection of mammals from Andaman and Nicobar Islands. Bulletin of the Indian Museum, $8,44-49$.

Oldham, R.D. (1885) Notes on the geology of the Andaman Islands. Records of the Geological Survey of India, 18, 135-145.

Palmeirim, J.M., Champion, A., Naikatini, A., Niukula, J., Tuinawa, M., Fisher, M. et al. (2007) Distribution, status and conservation of the bats of the Fiji Islands. Oryx, 41, 509-519.

Pande, P., Kothari, A. \& Singh, S. (eds) (1991) Directory of National Parks and Sanctuaries in Andaman and Nicobar Islands: Management Status and Profiles. Indian Institute of Public Administration, New Delhi, India.

Racey, P.A. \& Entwistle, A.E. (2003) Conservation ecology. In Bat Ecology (eds T.H. Kunz \& M.B. Fenton), pp. 680-743. Chicago University Press, Chicago, USA.

RAINEY, W.E. (1990) The flying fox trade becoming a rare commodity. Bats, 8, 6-9.

Rao, G.C. \& Dev Roy, M.K. (1985) The fauna of the Bay Islands. Journal of the Andaman Science Association, 1, 1-17.

RAO, G.C., RAO, D.V. \& DEVI, K. (1994) A faunal exploration of the North Reef Island Sanctuary, North Andaman. Journal of the Andaman Science Association, 10, 68-81.

RAO, N.V.S. (1984) Fauna of the Andaman and Nicobar Islands: diversity, endemism, erosion, and conservation strategies. In Andaman, Nicobar and Lakshadweep: An Environmental Impact Assessment (ed. C.J. Saldanha), pp 74-82. Oxford \& IBH, New Delhi, India.

Rodgers, W.A. \& Panwar, H.S. (1988) Biogeographical Classification of India. Wildlife Institute of India, Dehra Dun, India.

Rodrigues, A.S.L., Resit, H., Andelman, A., BaKarr, I.M., Boitani, L., Brooks, T.M. et al. (2004) Effectiveness of the global protected-area network in representing species diversity. Nature, $428,640-643$.

SAHA, S.S. (1980) Notes on some mammals recently collected from Andaman and Nicobar Islands. Records of the Zoological Survey of India, 77, 119-126.

SAnKaran, R. (1997) Developing a protected area network in the Nicobar Islands: the perspective of endemic avifauna. Biodiversity and Conservation, 6, 797-815.

SANKARAN, R. (1998) The Impact of nest collection on the edible nest swiftlet Collocalia fuciphaga in the Andaman and Nicobar islands. SACON Report. Salim Ali Centre for Ornithology and Natural History, Coimbatore, India.

Sankaran, R. (2001) The status and conservation of the Edible-nest Swiftlet (Collocalia fuciphaga) in the Andaman and Nicobar Islands. Biological Conservation, 97, 283-294.

Soisook, P., Karapan, S., Satasook, C., Thong, D., Khan, F.A.A. Maryanto, I. et al. (2013) A review of the Murina cyclotis complex (Chiroptera: Vespertilionidae) with descriptions of a new species and subspecies. Acta Chiropterologica, 15, 271-292.

Soota, T. D. \& Chaturvedi, Y. (1971) On the new locality record of a bat, Pipistrellus camortae Miller, from Car Nicobar and a note on its systematic status. Proceedings of the 58th Indian Science Congress Association, 3, 547-48.

Struebig, M.J., Christy, L., Pio, D. \& Meijaard, E. (2010) Bats of Borneo: diversity and representation in protected areas. Biological Conservation, 19, 449-469.

Struebig, M.J., Kingston, T., Zubaid, A., Mohd-Adnan, A. \& Rossiter, S.J. (2008) Conservation value of forest fragments to Paleotropical bats. Biological Conservation, 141, 2112-2126.

WiLes, G.J. (1987) Current research and future management of Marianas fruit bats (Chiroptera: Pteropodidae) on Guam. Australian Mammalogy, 10, 93-95.

Wiles, G.J., Engbring, J. \& Otobed, D. (1997) Abundance, biology and human exploitation in the Palau Islands. Journal of Zoology, 241, 203-227.

Zubaid, A. (1993) A comparison of the bat fauna between a primary and fragmented secondary forest in Peninsular Malaysia. Mammalia, 57, 201-206.

\section{Biographical sketches}

BANDANa AUL is researching the ecology of endemic species on the Andaman and Nicobar Islands and is currently working with The Bombay Natural History Society, Mumbai. PAUL BATES has spent the last 30 years researching the bats and small mammals of South and South-east Asia, and has helped develop a network of South-east Asian taxonomists working on mammals, birds and amphibians. DAVID HARRISON has been involved in research projects in South and South-east Asia. Currently, he is researching the fossil mammal fauna of Tertiary and Quaternary Britain. G. MAR IM U T HU specializes in the biology and behaviour of bats. He is founder Chairman of the Chiroptera Conservation Information Network of South Asia and member of the Scientific Advisory Board of Bat Conservation International. 